\title{
4. PUBLIC LAW AND THE PANDEMIC
}

\author{
Ana Raquel Gonçalves Moniz
}

\section{Introduction}

Protecting public health as a legal-constitutional asset, embodied in an objective health right, proves its transversality. This cross-cutting bundle of rights traverses all normative-social dimensions and all the legal dogma domains that are encountered during the pandemic. Therefore, it is conceivable that no other subject matter has experienced the influxes caused by the pandemic crisis with increasing intensity that are the hallmark of pandemic applications of Public Law. During the pandemic, public authorities gave paramount importance to achieving the right to health protection (addressing the impact on health services). Additionally, and of co-equal importance, public health measures to prevent and combat COVID-19 inevitably affect the ability to guarantee several fundamental rights.

In the context of pandemic response, invoking different kinds of states of exception presents problems that cross several legal and constitutional components of the infrastructure in public law systems. Many countries have experienced difficulty because emergency measures were often the product of legal-administrative actions. As the pandemic wore on from weeks to months to over a year, the grew increased negative reactions from citizens, who brought judicial actions against the various measures adopted under the declared State(s) of exception.

\section{Exceptionalism applied to the Emergency and how it Impacts Rights}

The reamrkably sudden emergence of COVID-19 forced legal systems to react through the mechanism(s) of the state(s) of exception. 
In Portugal, the 2020 pandemic caused mobilization of the figure of the state of emergency within the framework of the 1976 Constitution for the first time since its entry into force (even though emergency powers have been in the CRP from the outset). Unlike many countries ${ }^{1}$, western systems (including Lusophone legal systems) were faced with the legal projection of the effects of a pandemic in terms of fundamental rights, a crisis framed by a normative framework that is easily blurred. The admixture of these components gives rise to three questions: the distinction between situations of normality and situations of exception (2.1.); the central role played by the Executive, in the context of the response to the crisis (2.2.); the subordination of exceptional measures to juridicity, underlying that crisis measures do not operate beyond the rule of law.

\subsection{Fundamental rights: between normality and exception}

Current circumstances confront pre-existing distinctions between situations of normality and situations of exception; the divide between the "law of normality" and the "law of crisis" 2 In Portugal, fighting against the pandemic led to the mobilizating legal instruments of exception: both a constitutional state of exception (as happened with the

1 Necessary attention is due to the affected Eastern States, right at the dawn of the $21^{\text {st }}$ century, by the SARS outbreak, and whose reactions are seen as exemplary, since, after that epidemic, the response instruments were developed and improved, creating public health plans and, as such, giving public authorities a preparedness, which extended to the context of political and administrative planning and organization, which, in turn, resulted in faster and more efficient reaction mechanisms: this is what happened, for example, with Singapore or Taiwan. See SHAABAN/PELETEIRO/ MARTINS, "COVID-19: What Is Next for Portugal?», In: Frontiers in Public Health, vol. 8, 2020, 392 (doi: 10.3389 / fpubh.2020.00392). Also in the Macao Special Administrative Region, the SARS epidemic between 2001 and 2003 was an educational experience, which resulted in the approval of Law No. 2/2004 (law for the prevention, control and treatment of infectious diseases), the mechanisms of which were, immediately activated to face the pandemic - v. Vera RAPOSO / Man Teng IONG, "The Struggle Against CoViD-19 Pandemic in Macao», in: BioLaw Journal | Rivista di BioDiritto, special no. 1, 2020, pp. 747 and following.

2 Bacelar GouveiA, «Portugal e a COVID-19: Balanço e Perspetivas de uma Ordem Jurídica da Crise», in: Revista do Ministério Público, número especial COVID-19, ano 41, junho 2020, p. 94. 
state of emergency) and (special) "administrative states of exception" which are set out in the Civil Protection Framework Law (LBPC - Lei de Bases da Proteção Civil ${ }^{4}$ ), the Framework Law on Health (LBS - Lei de Bases da Saúde ${ }^{5}$ ), as well as the Public Health Surveillance System Law (LVSP - Lei do sistema de vigilância em saúde pública ${ }^{6}$ ). In general, and when perceived as forms of "states of emergency", these mechanisms embody a way of legalizing actions which, had they happened under other circumstances, would be invalid, but, in scenarios of imminent and/or existing danger to interests superior to those being sacrificed, a danger that is not imputable to the perpetrator of the injury.

Clearly, adopting each of the states of exception require verificating each of their own prerequisites and each has a (partly) different duration. Yet, from the perspective of how each of them affects fundamental rights, the respective effects differ. Under the Portuguese legal construct, if states of constitutional exception lead to the possibility of suspending the exercise of fundamental rights, the remaining mechanisms only result in their restriction - in line (at least, tendentially) with the seriousness of the underlying situations.

2.1.1. Thus, in the most serious situations - in which a state of siege or a state of emergency is decreed - article 19 of the Portuguese Constitution sets forth the possibility of suspending fundamental rights. Such a suspension is allowed only if it conforms to a set of limits outlined in the Constitution itself ; among those limits, we will underline two: one a structural-formal level; secondly, of a material nature.

On one hand, declarating a state of siege or a state of emergency presupposes a significant articulation between the sovereignty bodies: in Portugal, the President of the Republic, the Government and the Parliament embody a system of checks and balances as it arises from

3 See also: Pedro Gonçalves, Manual de Direito Administrativo, vol. 1, Almedina, Coimbra, 2019, pp. 391 and 392, distinguishing between the state of administrative need (as a general rule contained in the CPA - Code of Administrative Procedure) and the "special rules of emergency law" (italics in the original), which embody a different specific regime.

4 Law no. 27/2006, of July $3^{\text {rd }}$, amended by Organic Law (Lei Orgânica) no. $1 / 2011$, November $30^{\text {th }}$ and Law no. 80/2015, of August $3^{\text {rd }}$.

5 Approved by Law No. 95/2019, of September $4^{\text {th }}$.

6 Law No. 81/2009, of August $21^{\text {st }}$. 
an adequate understanding of the principle of separation and interdependence between powers. Prior to a presidential declaration of state of emergency, there must be a hearing within the Government, and requires authorization by the Assembly of the Republic (according to articles $138,161 / 1)$, and 197/1/f), of the Portuguese Constitution $\left.{ }^{7}\right]$, as well as parliamentary control of its specific execution (see article 162/b] of the $\mathrm{CRP}^{8}$ ). Additionally, the declaration of a state of siege or a state of emergency maintains the constitutional scheme for organizing political power (including the self-governing bodies of the autonomous regions) thus untouched (see article 19/7), from CRP).

On the other hand, it must be emphasized that the constitutional state of exception regime has material limits. From the outset, and without interfering on the essential observance of the requirements of the principle of proportionality (cf., in particular, article 19, sections 4 and 8 , of the Portuguese Constitution) and the principle of exceptionality and limits on suspension ${ }^{9}$, the number 6 of article 19 of the Portuguese Constitution prevents the suspension of the rights to life, personal integrity, personal identity, civil capacity and citizenship, non-retroactivity of criminal law, the right of defence of defendants and the freedom of conscience and religion.

The Portuguese influence in Lusophone countries is noticeable, many of them opting for a constitutional state of exception system, which, also with the aim of restoring constitutional order, provide for the possibility of suspension (and, in certain cases, of limitation) of fundamental rights, temporarily (cf. table 1).

7 See also article 10 of the State of siege and State of emergency regime (Regime do estado de sitio e do estado de emergência, RESEE - Law no. 44/86, of September 30 th, amended by Framework Laws (Leis Orgânicas) no. 1/2011, of November $30^{\text {th }}$, and no. $1 / 2012$, of May $11^{\text {th }}$ ). The steps involved in the process are contemplated in articles 23 and following of this same act.

The decree of the President of the Republic declaring a state of siege or a state of emergency [cf. article 134/1/d) of the Portuguese Constitutionl] is subject to ministerial referendum, in accordance with the provisions of paragraph 1 of article 140 of the Constitution. See also article 11 of the RESEE).

8 See also article 28 of the RESEE.

9 Cf. Jorge Miranda, «Artigo 19. ${ }^{»}$, in: Jorge Miranda/Rui Medeiros (dir.),

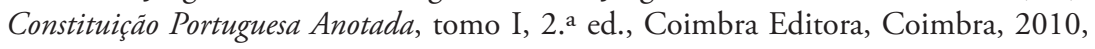
p. 410 . 
Articles 282 to 284 of the Constitution of Mozambique thus enshrines the concepts of state of siege and the state of emergency, declared in the event of an agression (or imminent aggression), serious threat, disturbance of the constitutional order or situations of public calamity (reserving the state of emergency for cases in which these preconditions are verified but are less severe). Declaration of the state of emergency allows suspension and limitation of rights, not exceeding 30 days, (although it may be extended for equal periods of 30 days, up to three times, if so justified). Article 58 of the Angolan Constitution includes the mechanisms of the state of war, state of siege and state of emergency, to be mobilized in situations of effective or imminent aggression by foreign forces, of serious threat or disturbance of the democratic constitutional order or situations of public calamity. These states of exception produce the suspension and limitation of rights (without the possibility of affecting the right to life, personal integrity and personal identity, civil capacity and citizenship, as well as the non-retroactivity of criminal law, the right of defence and freedom of conscience and religion).

The Brazilian Constitution establishes a more significant material duality between the emergency State of defense and the State of siege, which projects on the design of the applicable legal regimes (cf. articles 136 and 137 of the Federal Constitution, respectively): the former is dedicated to the preservation or the prompt restoration of public order or social peace (threatened by serious and imminent institutional instability or affected by calamities of great proportions) and exclusively allows the restriction of rights in limited and determined areas (with a duration not exceeding 30 days, without prejudice to the possibility of one prorrogation, for an equal period). The latter option is designed to address serious commotions with national repercussions, or is pin the aftermath facts that prove the ineffectiveness of the measures adopted during the state of defense, declaration of state of war or as a response to foreign armed aggression. This state of siege involves the suspension of rights (for a period not exceeding 30 days - successive extensions for equal periods are allowed - or, when applicable, for the duration of the war or armed aggression).

2.1.2. In parallel but independent from this very specific regime, the Portuguese system sets out regulations that allow the adoption of exceptional measures in very different circumstances (not all associated 
- rectius, regardless of their association - to the protection of public health). This can occur using instruments resulting from the LBPC: the declarations of a situation of alert, contingency or calamity consist of mechanisms generally intended for mitigating collective risks by limiting their effects in the event of a serious accident or catastrophe (cf. article 1 of the LBPC). These declarations presume increasing severity of the situation which in turn is projected in the intensity of the measures to be adopted and in the body vested with powers to issue them (cf. articles 8, 9. 13 and following of the LBPC). In particular, legal actions and material operations carried out under the declaration of a calamity situation and for the purpose of executing this declaration are presumed to be carried out in a state of need (cf. Article 23, number 2 of the LBPC) and may involve limitations on fundamental rights, such as private property or free private economic initiative (cf. Articles 23/1, and 24 of the LBPC).

In the context of public health crises, Article 17 of the public LVSP gives extensive powers to the member of the Government responsible for the area of health. Contrary to the implied power in its title ("exceptional regulatory power"), this rule includes exceptional measures that are not restricted to merely issuing regulations. Instead, this norm provides generic authorization for the practice of administrative acts that imply restriction, suspension or closure of activities, and separation of people who are not sick, means of transport or goods that have been exposed to infection or contamination, in order to contain pandemic spread. Therefore, under this precept, the Government can adopt (primary?) measures that restrict fundamental rights, limiting, for example, the freedom of movement, the right of assembly or the right to private economic initiative.

\subsection{The centrality of the Executive}

Operationalization of the "law of the crisis" signifies, as a rule, a rebalancing of the various powers, determining the centrality of the executive power, in general, and the Government, in particular. Thus, the situations of exception and the responses that are designed to react to them inevitably lead to a stronger Executive, even when (as in Portugal) competence for the declaration (of the state of emergency) is entrusted to the Head of State endowed with direct democratic legitimacy. 
2.2.1. From the outset, the national execution of the declaration of the state of emergency is entrusted to the Government (cf. article 17 of the RESEE), as the highest organ of Public Administration. It should also be noted that the CRP uses the expression "authorities" (cf. article 19/8 which is repeated by article 19 of the RESEE) to designate the entities which have the competence of adopting the appropriate and necessary measures for the prompt restoration of the constitutional order - which, in turn, refers to the Administration ${ }^{10}$ [naturally, under the direction (hoc sensu) of the Government] a determinative role, not only shaping the measures that are adopted, but also forming their execution. Although the law imposes a duty to inform the President of the Republic and the Assembly of the Republic regarding the measures that enforce the state of emergency, this does not exclude the government's role, but emphasizes the importance of this organ's political accountability to others.

The importance of the administrative regulation is significant: in fact, the rules contained in the various government decrees that have implemented the declaration of the state of emergency issued by the President of the Republic assume the nature of administrative regulations ${ }^{11}$. This form of administrative action has an enforcement function here, as a normative instrument that is essential to define the legal policies that result from the declaration of the constitutional state of exception.

2.2.2. The declaration of the calamity situation, based on the LBPC, also reinforces centrality of the Government. In situations of serious public health emergencies, particularly in the event of a calamity or catastrophe, the member of the Government who are responsible for health must institute all necessary exceptional measures that are indispensable to the situation, coordinating the contribution of the

10 On the specific context of the state of siege/state of emergency, cf. Bacelar GOUVEIA, Estado..., cit., P. 190.

11 See Decrees No. 2-A/2020, of March $20^{\text {th }}, 2-B / 2020$, of April $2^{\text {nd }}, 2-C / 2020$, of April 17th $2-\mathrm{D} / 2020$, of April $30^{\text {th }}, 8 / 2020$, of November $8^{\text {th }}, 9 / 2020$, of November $21^{\text {st }}, 11 / 2020$, of December $6^{\text {th }}, 11-\mathrm{A} / 2020$, of December $21^{\text {st }}, 2-\mathrm{A} / 2021$, of January $7^{\text {th }}, 3-\mathrm{A} / 2021$, of January $14^{\text {th }}, 3-\mathrm{B} / 2021$, of January $19^{\text {th }}, 3-\mathrm{C} / 2021$, of January $22^{\text {nd }}, 3-\mathrm{D} / 2021$, of January $29^{\text {th }}, 3-\mathrm{E} / 2021$, of February $12^{\text {th }}, 3-\mathrm{F} / 2021$, of February $26^{\text {th }}$, and Decree No. $4 / 2021$, of March $13^{\text {th }}$. 
central services of the Ministry with the institutions and services of the National Healthcare System and health authorities at national, regional and municipal levels (cf. article 5, no. 4, of Decree-Law no. 82/2009). Consistent with these precepts, the aforementioned Law no. 81/2009, which establishes that, in the event of a public health emergency, there are exceptional administrative powers granted to the member of the Government responsible for the health area (cf. article 17). In this normative scope, the practical problems that arose can be traced back to the circumstance that, during the firste wave, some of the measures adopted under the declaration of the state of emergency were extended beyond it and also adopted under the declaration of calamity or under the health surveillance system.

\subsection{Jurisdictional means of defending fundamental rights}

Prerequisites and preconditions to declare the states of exception set out in the Constitution and the Law clearly indicate that the legislator is not acting outside the principle of legality, but, on the contrary, that public authorities are still acting within the framework of the rule of law.

Safeguarding (possible) violation of the right to freedom (and, therefore, litigation for example in reaction against an illegal detention), the remedies used to control the legality of actions performed by public authorities (when they affect fundamental rights) are primarily derived from Administrative Justice and/or Constitutional Justice. Among us (but similarly to what happens in other legal systems), there are already some (although not many) cases that, having reached the Constitutional Court ${ }^{12}$ or the Supreme Administrative Court $^{13}$, dealt with the

12 See Judgments no. 424/2020, of July $31^{\text {st }}$, and no. 687/2020, of November $26^{\text {th }}$. In the meanwhile, a request for the general review of constitutionality of rules that deal with property right and free private economic initiative, has already been submitted by the Ombudsman to the Constitutional Court on November 23 ${ }^{\text {rd }}, 2020$, but, due to the absence of deadline associated with this process, has not yet been decided upon.

13 See Judgments of 10.09.2020 (P. 088 / 20.8BALSB), 31.10 .2020 (P. 01958 / 20.9BELSB) and 31.10.2020 (P. $0211 / 20.1$ BALSB), Orders of 20.11.2020 (P. 2090 /20.0BELSB) and of 23.12.2020 (P. 143 / 20.4BALSB), and Judgment of 05.02.2021 (P. 012 / 21.0BALSB). 
constitutionality/legality of the measures adopted in the context of the pandemic that contend with fundamental rights (see table 3).

A preliminary analysis of the jurisprudence available in Portugal allows us to anticipate three possible outcomes:

a) As far as administrative jurisdiction is concerned, despite not having data regarding the courts of first instance, in comparative terms (to, for example, German and French cases), there are relatively few cases that are aimed at defending fundamental rights. It does not seem to us, however, that it is possible to infer from this fact that the measures adopted do not raise questions regarding their constitutional or legal conformity (on the contrary: these questions are clear in the Judges' voting results of two of the decisions);

b) There have been two Constitutional Court's judgements in appeals within the judicial review process, but most court proceedings aimed at protecting fundamental rights were directed to the Administrative Justice, in particular through the writ for the protection of rights, freedoms and guarantees (intimação para a proteção de direitos, liberdades e garantias). These decisions, as they are qualified as an urgent court proceeding, were rendered quickly, which translates the fulfillment of the right of effective judicial protection and consolidates the role of the Courts as guardians of fundamental rights and the rule of law;

c) Assessing the legal conformity of the measures lead to the mobilization of fundamental normative principles, as happened, paradigmically, with the principle of proportionality or with the principle of equality. However, summoning such principles also ended up revealing some of the perplexities underlying the valuation judgments they presuppose and the weaknesses emerging from their traditional understandings.

\section{Final Reflections}

In light of the exceptional circumstances under the pandemic of 2020 and its attendant emergency orders, the legal projections of the pandemic turn out, to be a "stress test" of the rule of law itself, whose defence takes on special relevance in times of crisis. The current expe- 
rience opens the way for further reflection, both in terms of Constitutional Law and in terms of Administrative Law.

The lack of legal instruments for responding to the pandemic has generated some uncertainty regarding the form and degree of how rights are affected - a concept which is one of the pillars of the Rule of Law. In terms of right(s), this crisis confirms that preparedness represents a fundamental aspect for the evolution of legal regimes, imposing an a posteriori reflection and improvement on the matter ${ }^{14}$. In this context, it stands out, in Europe (and, therefore, in a legal-cultural horizon closer than the Asian experiences), the German Infektionsschutzgesetz which, having entered into force in 2001, established a relatively solid legal framework for similar situations (although without the dimension of COVID-19), but which, nevertheless, had to undergo significant changes during the pandemic, including the introduction of a State of "epidemiological situation of national importance".

In any legal system, if a government wishes to design a heightened preparedness strategy for pandemics based on epidemiology to protect people during a public health emergency, it will require more than a mere adequate articulation with the existence of a constitutional state of exception based on public calamity (or equivalent institute), as well as a reflection and consideration on the subject of conformation / limitation / restriction of fundamental rights (especially rights, freedoms and guarantees) and the possibility and degree of normative intervention of the Administration. Drafting new laws about this subject will enjoy the advantage of lessons learned, to be better equipped to respond to a pandemic situation. In addition to specific problems related to the legitimacy of the interference of the law in the practice of

14 The Portuguese legal system was almost due to achieve a leading position in this matter: in fact, Base XIII of the Draft Framwork Law on Health (cf. Lei de Bases da Saúde: Materiais e Razóes de um Projeto, Cadernos da Lex Medicinae n. ${ }^{\circ}$ 3, Instituto Jurídico | Faculdade de Direito da Universidade de Coimbra, Coimbra, 2018, pp. 47 e s.) provided for the development and implementation of health observation instruments, namely for epidemiological monitoring and surveillance, as well as the development of a public health system that would make it possible to identify, assess, manage and communicate risk situations in relation to communicable diseases and other threats to public health, and the systematic preparation and updating of contingency plans in the face of emergency or public calamity situations, determining the temporary measures necessary to protect public health. Unfortunately, none of these aspects would end up being set out in Base 10 of the new LBS ... 
medicine (for example, when testing patients), there are also problems regarding the scope of protection for fundamental rights (and, concommitantly, determining how those rights may lawfully be restricted). For example, the right to privacy data confidentiality (and the very different questions that arise either from the possible mandatory use of location tracking mechanisms and contact tracking through mobile digital applications, registration of vaccinated persons and having their data publicized namely through the issuance of "COVID-19 immunity passports" or "health certificates", or the control of body temperature) can be addressed in a transparent and accessible manner when writing new laws for pandemic preparedness. So too, rights to physical integrity (underlying issues related to mandatory vaccination), or economic freedom, and managing traffic within communication networks, all can be discussed in an open manner with input form stakeholders. Lastly, this approach can embrace material dimensions related to the principle of proportionality, or the formal dimensions related to the principle of the determinability of norms or the heightened normative density that characterises all the provisions that are related to rights, freedoms and guarantees.

Considering that the pandemic brings both health and economic consequences that constitute a normatively relevant social challenge, these aspects of the pandemic require reflection in order to determine which significant changes in the development of public law are acceptable without undermining cornerstone structural principles of the rule of law, democracy and sociality. 


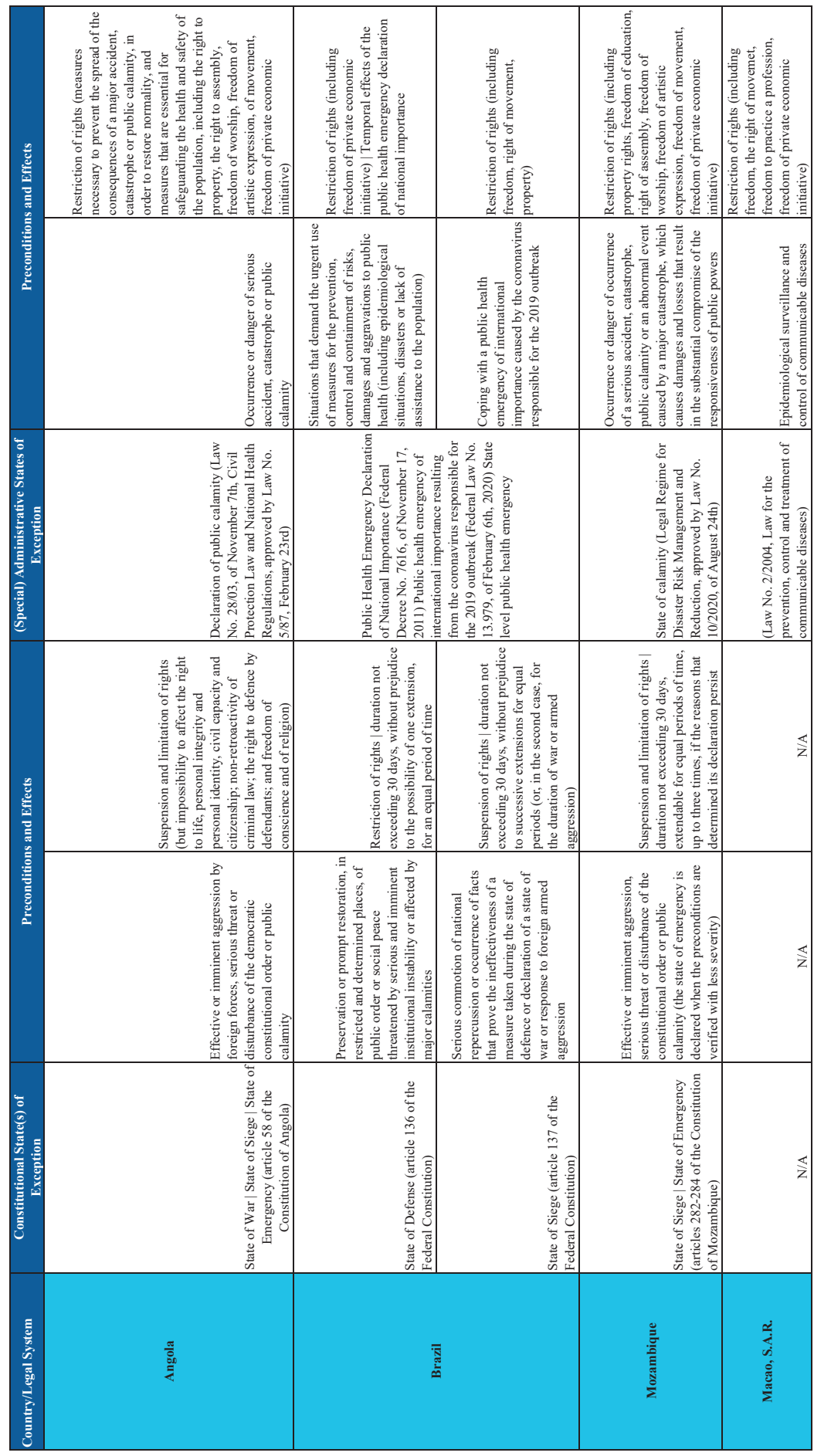


Public Law and the Pandemic 59

\begin{tabular}{|c|c|c|c|c|c|c|c|c|c|c|}
\hline ") & 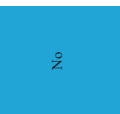 & 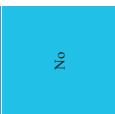 & $\frac{1}{z}$ & $\stackrel{\gtrless}{z}$ & 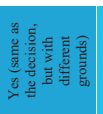 & 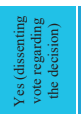 & $\widehat{\Sigma}$ & $\widehat{\S}$ & $\widehat{\bar{z}}$ & ฉ \\
\hline 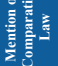 & $\AA$ & $\stackrel{z}{z}$ & $\$$ & $\stackrel{\mathscr{\vartheta}}{\rightleftharpoons}$ & & $\stackrel{\circ}{z}$ & $\frac{\pi}{z}$ & $\bar{z}^{\prime}$ & $\frac{\pi}{z}$ & $\stackrel{q}{z}$ \\
\hline 庇 & 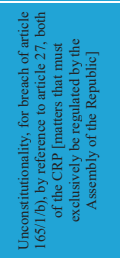 & 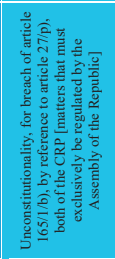 & $\Sigma_{z}$ & 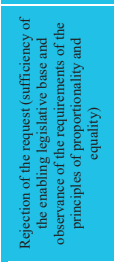 & & 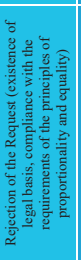 & $\frac{\bar{g}}{2}$ & 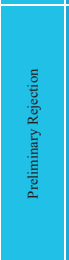 & & 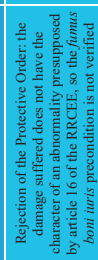 \\
\hline 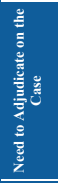 & 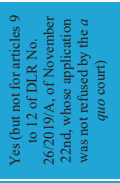 & $\stackrel{x}{\mathscr{x}}$ & $\Sigma_{z}$ & $\stackrel{\leftrightarrow}{\mathscr{*}}$ & 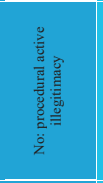 & $\ddot{:}$ & 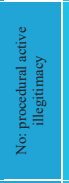 & 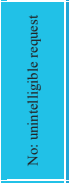 & 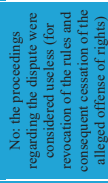 & $\ddot{x}$ \\
\hline 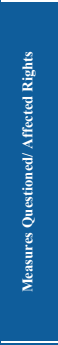 & 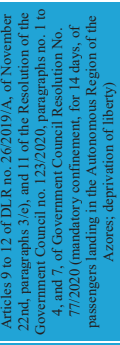 & 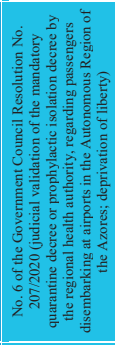 & 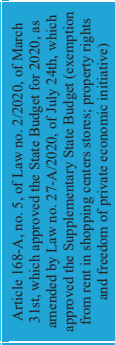 & 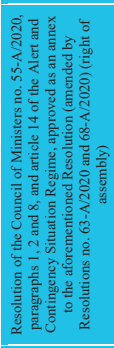 & 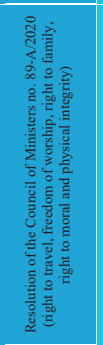 & 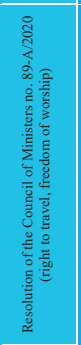 & 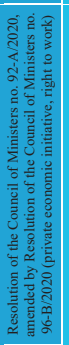 & $\widehat{\underline{z}}$ & 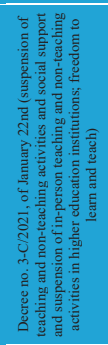 & 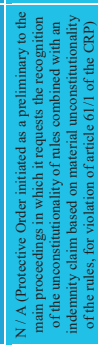 \\
\hline $\begin{array}{l}0 \\
\end{array}$ & 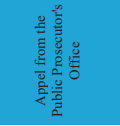 & 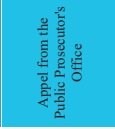 & 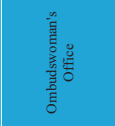 & हี & 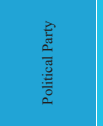 & 遌 & 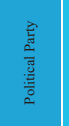 & 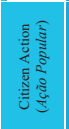 & & 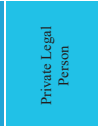 \\
\hline 宷 & $\begin{array}{l}0 \\
\vdots\end{array}$ & 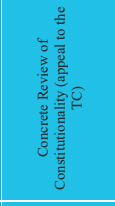 & 弟 & 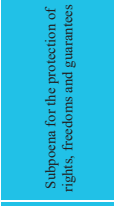 & 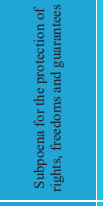 & 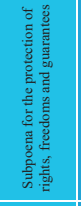 & 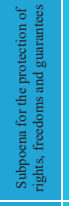 & 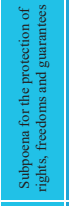 & 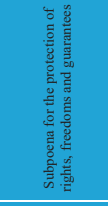 & 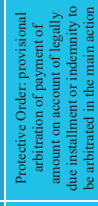 \\
\hline 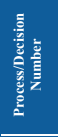 & 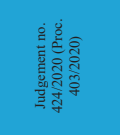 & 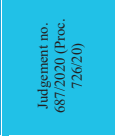 & $\Sigma_{z}$ & 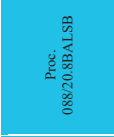 & 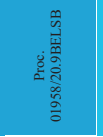 & 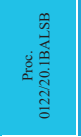 & 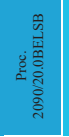 & 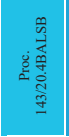 & 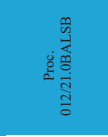 & 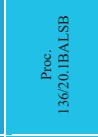 \\
\hline 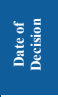 & 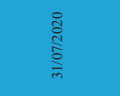 & 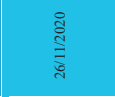 & 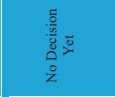 & 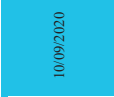 & हั่ & ్ㅠㅁ & 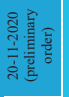 & 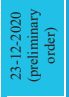 & तิ & 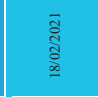 \\
\hline 总言 & $\begin{array}{l}\text { : } \\
\text { के } \\
\text { के }\end{array}$ & $\begin{array}{l}\text { के } \\
\text { डे } \\
\text { ते }\end{array}$ & ֻั & 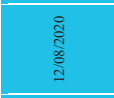 & 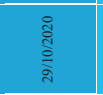 & कूี่ & : & & 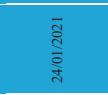 & 突 \\
\hline है & 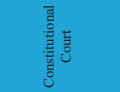 & 童 & है & 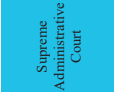 & 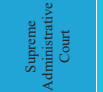 & 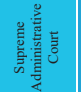 & 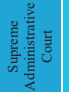 & 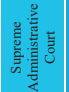 & 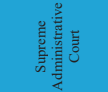 & 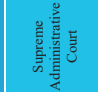 \\
\hline
\end{tabular}




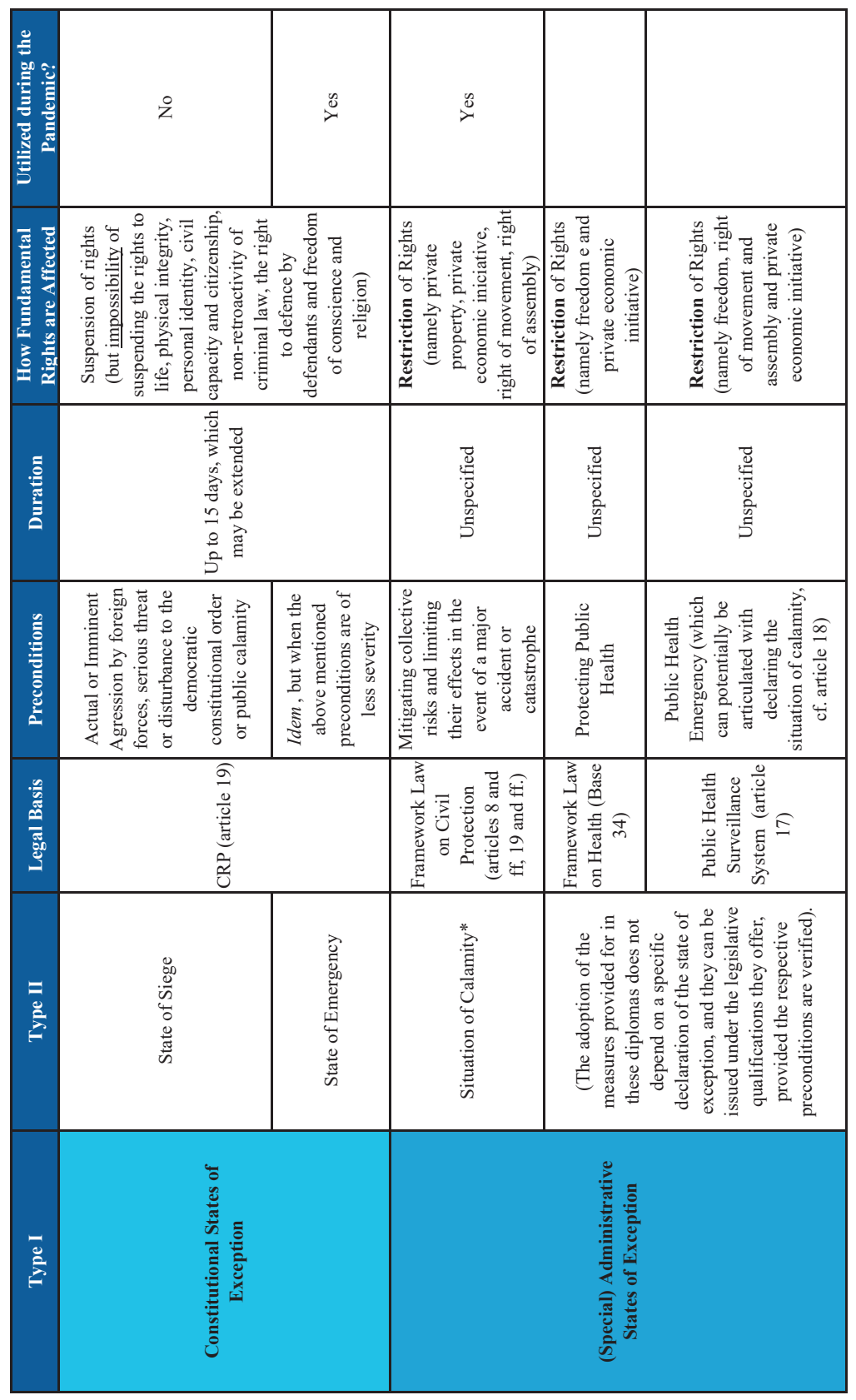

